\title{
PENGETAHUAN IBU HAMIL TENTANG KEK (KEKURANGAN ENERGI KRONIS) \\ PADA KEHAMILAN DI PUSKESMAS REJOSARI TAHUN 2015
}

Widya Juliarti, Yuliantika

STIKes Hang Tuah Pekanbaru

\begin{abstract}
Chronic energy deficiency in pregnancy is a state where mothers with chronic food shortages lasting (chronic) which gives rise to health problems in the mother. In 2014 the number of pregnant women who have obtained Rejosari health centers KEK in 99 pregnant women have KEK.Studi introduction of KEK obtained 4 people who are less knowledgeable about the KEK, this study aims to determine Overview Knowledge About Pregnancy KEK (chronic energy deficiency) In pregnancy in Puskesmas Rejosari. This research method is descriptive conducted on 26th February to May 23, 2015 in Pekanbaru Rejosari health center. Sampling technique accidental sampling with a sample size of 100 orang.Pengumpulan data using questionnaires and data processing is done manually by univariate analysis. From the results of the study on 100 respondents obtained, sebanyak96 less knowledgeable respondents (96\%). Knowledgeable were higher by 4 respondents (4\%). Conclusions knowledge of KEK pregnant women at health centers Rejosari in getting the results that the majority of respondents have less penegetahuan Rejosari 96. It is recommended in health center MCH services, especially health workers and cadres to prioritize the provision of education on health centers and at KEK in Posyandu activities.
\end{abstract}

Keywords: Postpartum Mother, Papaya Fruit, Breast Milk Production

\begin{abstract}
ABSTRAK
Kurang Energi Kronis pada kehamilan adalah keadaan dimana ibu penderita kekurangan makanan yang berlangsung menahun (kronis) yang mengakibatkan timbulnya gangguan kesehatan pada ibu. Pada tahun 2014 jumlah ibu hamil yang mengalami KEK di Puskesmas Rejosari diperoleh 99 ibu hamil yang mengalami KEK.Studi pendahuluan tentang KEK diperoleh 4 orang yang berpengetahuan kurang tentang KEK, Penelitian ini bertujuan untuk mengetahui Gambaran Pengetahuan Ibu Hamil Tentang KEK (kekurangan energi kronis) Pada Kehamilan di Puskesmas Rejosari. Metode penelitian ini adalah deskriftif yang dilakukan pada tanggal 26 Februari- 23 Mei 2015 di Puskesmas Rejosari Pekanbaru. Teknik pengambilan sampel secara accidental sampling dengan jumlah sampel 100 orang. Pengumpulan data menggunakan kuesioner dan pengolahan data dilakukan secara manual dengan analisa Univariat. Dari hasil penelitian pada 100 responden didapatkan, berpengetahuan kurang sebanyak96 responden (96\%). Berpengetahuan yang tinggi sebanyak 4 responden (4\%). Kesimpulan pengetahuan ibu hamil tentang KEK di Puskesmas Rejosari di dapatkan hasil bahwa mayoritas responden memiliki penegetahuan kurang 96. Disarankan pada Puskesmas Rejosari khususnya tenaga kesehatan pelayanan KIA dan kader dapat memprioritaskan pemberian penyuluhan tentang KEK di Puskesmas maupun pada kegiatan Posyandu.
\end{abstract}

Kata Kunci : Pengetahuan, KEK, Ibu Hamil 


\section{PENDAHULUAN}

Ibu KEK adalah ibu yang ukuran LILAnya $<23,5 \mathrm{~cm}$ dan dengan salah satu atau beberapa kriteria sebagai berikut : a. Berat badan ibu sebelum hamil $<42 \mathrm{~kg}$. $\mathrm{b}$. Tinggi badan ibu $<145 \mathrm{~cm}$. c. Berat badan ibu pada kehamilan trimester III $<45 \mathrm{~kg}$. d. Indeks masa tubuh (IMT) sebelum hamil < 17,00 e.Ibu menderita anemia $(\mathrm{Hb}<11$ gr \%) (Weni, 2010).

Ibu hamil yang menderita KEK, mempunyai resiko yang lebih besar untuk melahirkan bayi dengan Berat Badan Lahir (BBLR), kematian saat persalinan, perdarahan, pasca persalinan yang sulit karena lemah dan mudah mengalami gangguan kesehatan. Bayi yang dilahirkan dengan BBLR akan meningkatkan risiko kesakitan dan kematian pada bayi 27,6\% sampai 3,92\% mampu meredam tekanan lingkungan yang baru sehingga dapat berakibat pada terhambatnya pertumbuhan dan perkembangan, bahkan dapat menganngu kelangsungan hidupnya (Depkes RI, 2010).

Beberapa faktor yang mempengaruhi KEK (Kekurangan Energi Kronis) adalah paritas, jarak kelahiran, usia ibu dan pengetahuan. Paritas adalah jumlah anak yang dilahirkan oleh ibu. Dalam hal ini dikatakan terlalu banyak melahirkan adalah lebih dari 3 kali. Manfaat riwayat obstetrik ialah membantu besaran kebutuhan zat gizi karena terlalu sering hamil dapat menguras cadangan zat gizi tubuh (Arisman, 2004). Jarak kelahiran yang terlalu dekat (kurang dari 2 tahun) pada ibu hamil menyebabkan status gizi ibu kurang karena tubuh tidak

diberi kesempatan untuk pemulihan keadaan gizi, dengan demikian sebaiknya ibu hamil mempunyai jarak kehamilan lebih dari 2 tahun. Maka anak akan memiliki probabilitas hidup lebih tinggi dan kondisi anaknya lebih sehat dibandingkan anak dengan jarak kelahiran di bawah 2 tahun (Wilopo, 2004).

Melahirkan anak pada usia ibu yang muda atau terlalu tua mengakibatkan kualitas janin/anak yang rendah dan juga akan merugikan kesehatan ibu (Farida, 2004). Pemilihan makanan dan kebiasaan diet dipengaruhi oleh pengetahuan terhadap makanan dan praktek-praktek pengetahuan tentang nutrisi melandasi pemilihan makanan. Pengetahuan gizi yang baik, apabila masyarakat itu telah memberikan aturan makan yang baik untuk diri dan keluarganya. Sebaliknya masyarakat yang pengetahuannya tentang gizi rendah, dapat mengakibatkan kekurangan gizi atau malnutrisi (Joyomartono, 2004).

Di Indonesia banyak terjadi kasus KEK (Kekurangan Energi Kronis) terutama yang kemungkinan disebabkan karena adanya ketidakseimbangan asupan gizi, sehingga zat gizi yang dibutuhkan tubuh tidak tercukupi. Hal tersebut mengakibatkan perumbuhan tubuh baik fisik ataupun mental tidak sempurna seperti yang seharusnya. Banyak anak yang bertubuh sangat kurus akibat kekurangan gizi atau sering disebut gizi buruk. Jika sudah terlalu lama maka akan terjadi Kekurangan Energi Kronik (KEK). Hal tersebut sangat memprihatinkan, 
mengingat Indonesia adalah negara yang kaya akan SDA (Sumber Daya Alam).

Kejadian KEK di Indionesia banyak terjadi, terutama yang disebabkan karena adanya ketidak seimbangan asupan gizi, sehingga zat gizi yang dibutuhkan tubuh tidak tercukupi. Hal tersebut mengakibatkan pertumbuhan fisik tubuh maupun mental bayi yang dilahirkan tidak sempurna seperti yang seharusnya. Tahun 2013, prevalensi ibu hamil dengan KEK masih cukup tinggi di Indonesia yaitu 38,5\% (Rikesdas, 2013). Dan pada Tahun 2014 masih ada ibu hamil yang menderita KEK yaitu 24,0 \% meskipun pemerintah sudah menjalankan program atau upaya-upaya menurunkan KEK pada kehamilan (Depkes, 2014). Prevalensi ibu hamil dengan KEK di Provinsi Riau sendiri masih tinggi, pada tahun 2014 yaitu sebesar $42,8 \%$, hal ini merupakan masalah yang harus mendapatkan perhatian dari berbagai pihak.

Berdasarkan data dari Dinas Kesehatan Kota Pekanbaru pada Tahun 2012 prevalensi KEK pada kehamilan masih cukup tinggi yaitu sebanyak 468 orang dari $21.427 \mathrm{ibu}$ hamil. Tidak terlihat perbedaan yang bermakna dari tahun sebelumnya pada tahun 2013 angka kejadian KEK masih tinggi, dari $21.635 \mathrm{ibu}$ hamil terdapat 345 orang ibu hamil yang mengalami KEK. Pada tahun 2013. Dan pada tahun 2014 angka kejadian KEK masih tinggi, dari 2.624 ibu hamil terdapat 73 orang ibu hamil yang mengalami KEK. Dari 21 Puskesmas yang yang ada di kota Pekanbaru, puskesmas Rejosari merupakan puskesmas dengan jumlah kejadian KEK terbanyak, dari 2.624 ibu hamil terdapat 99 orang $(3,77)$ mengalami KEK (Kekurangan Energy Kronis) dalam kehamilan.

Hasil survey yang dilakukan di Puskesmas Rejosari dilakukan uji validitas yaitu dari ibu hamil yang diambil bulan Desember tahun 2014 jumlah ibu hamil 2,624 ibu hamil. Dari ibu hamil tersebut melakukan survey dengan 10 orang ibu hamil, didapatkan 6 orang yang mengetahui KEK (Kekurangan Energi Kronis) dan 4 orang yang tidak mengetahui KEK (Kekurangan Energi Kronis). Berdasarkan latar belakang diatas, oleh karena itu penelitian ingin melakukan penelitian dengan judul " Gambaran Pengetahuan Ibu Hamil tentang KEK (Keurangan Energi Kronis) Pada Kehamilan Di Puskesmas Rejosari Tahun 2015".

\section{METODE}

Jenis Penelitian ini merupakan deskriftif. Populasi dalam penelitian ini adalah seluruh ibu hamil yang melakukan kunjungan di Puskesmas Rejosari periode tahun 2015. Sampel dalam penelitian ini adalah sebagian ibu hamil yang melakukan kunjungan di Puskesmas Rejosari periode bulan November tahun 2014 s/d bulan Januari tahun 2015. Pengambilan sampel dilakukan dengan teknik (Accidental Sampling) yaitu Pengambilan sampel didasarkan pada kenyataan bahwa mereka kebetulan muncul. Analisis data yang digunakan adalah analisi univariat. 
HASIL

1. Karakteristik Responden

a. Umur

Tabel 1

Karakteristik Ibu Hamil Berdasarkan

Umur

di Puskesmas Rejosari Tahun 2015

\begin{tabular}{ccc}
\hline Umur & F & \% \\
\hline$<20$ & 2 & $2 \%$ \\
$20-35$ & 85 & $85 \%$ \\
$>35$ & 13 & $13 \%$ \\
\hline Jumlah & 100 & $100 \%$ \\
\hline
\end{tabular}

Berdasarkan tabel 2 distribusi frekuensi responden dapat dilihat bahwa miyoritas responden berumur dibawah 20-35 tahun 85 orang $(85 \%)$.

\section{b.Pendidikan}

Tabel 2

Karakteristik Ibu Hamil Berdasarkan Pendidikan di Puskesmas RejosariTahun 2015

\begin{tabular}{ccc}
\hline $\begin{array}{c}\text { Tingkat } \\
\text { Pendidikan }\end{array}$ & F & \% \\
\hline Rendah & 27 & $27 \%$ \\
Tinggi & 73 & $73 \%$ \\
\hline Total & 100 & $100 \%$ \\
\hline
\end{tabular}

Dari tabel 3 distribusi frekuensi responden dapat dilihat bahwa mayoritas responden tingkat pendidikan tinggi (SMA/ STM dan Akademik/ perguruan tinggi) berjumlah 73 orang $(73 \%)$.

\section{c. LILA (Lingkar Lengan Atas)}

Tabel 3

Karakteristik Ibu Hamil Berdasarkan LILA di Puskesmas Rejosari Tahun 2015

\begin{tabular}{ccc}
\hline Umur & F & \% \\
\hline$<23,5$ & 27 & $27 \%$ \\
$>23,5$ & 74 & $74 \%$ \\
\hline
\end{tabular}

Pada tabel 4 dapat dilihat dari 100 responden, diketahui sebanyak $74 \%$ responden memiliki ukuran lingkar lengan atas (LILA) $>23.5 \mathrm{~cm}$.

\section{Pengetahuan Ibu Hamil Tentang KEK}

(Kekurangan Energi Kronis)

Tabel 4

Distribusi Frekuensi Tingkat Pengetahuan Ibu Hamil tentang KEK di Puskesmas Rejosari Tahun 2015

\begin{tabular}{lcc}
\hline Pengetahuan & F & \% \\
\hline Rendah & 96 & $96 \%$ \\
Tinggi & 4 & $4 \%$ \\
\hline Jumlah & 100 & $100 \%$ \\
\hline
\end{tabular}

Pada tabel 5 dapat dilihat dari 100 responden, diketahui sebanyak 96\% responden memiliki pengetahuan yang rendah tentang KEK di Puskesmas Rejosari.

\section{PEMBAHASAN}

Hasil penelitian tentang pengetahuan KEK, diketahui pada kehamilan (96\%) responden memiliki pengetahuan yang rendah, mayoritas respoden berumur 2035 tahun 85 orang (85\%), tingkat pendidikan tinggi (SMA/STM dan Akademik/ perguruan tinggi) berjumah 73 orang (73\%), dan diketahui sebanyak 74 orang $(74 \%)$ responden memiliki lingkar lengan atas (LILA) $.23,5 \mathrm{~cm}$ di Puskesmas Rejosari Tahun 2015. Hal ini sejalan dengan teori Notoatmojo (2005), pengetahuan adalah hasil penginderaan manusia, atau hasil tahu seseorang 
terhadap objek melalui indera yang dimilikinya (mata, hidung, telinga, dan sebagainya), sebagian besar pengetahuan seseorang diperoleh melalui indera pendengaran (telinga), dan penglihatan(mata).

Pengetahuan seseorang akan berpengaruh terhadap gizi seseorang, untuk masyarakat yang berpendidikan dan cukup pengetahuan tentang gizi, pertimbangan fisiologis lebih menonjol dibandingkan dengan kebutuhan psikis. Beberapa studi mengatakan bahwa jika tingkat pengetahuan ibu meningkat maka pengetahuan nutrisi dan praktik nutrisi bertambah baik, usaha-usaha untuk memilih makanan yang bernilai nutrisi makin meningkat, ibu-ibu rumah tangga yang mempunyai pengetahuan nutrisi akan memilih makanan yang lebih bergizi daripada yang kurang bergizi (Joyomartono, 2004).

Hasil penelitian ini tidak jauh berbeda dengan hasil penelitian yang dilakukan oleh Mustika Hidayati (2013) tentang “ Kurang Energi Kronis dan Anemia Ibu Hamil Sebagai Faktor Resiko Kejadian Berat Bayi lahir Rendah Dikota Mataram" menyatakan bahwa menunjukkan 60 orang yang berpengetahuan kurang tentang KEK (kekurangan energi kronis), mayoritas respoden berumur 20-35 tahun 54 orang (54\%), tingkat pendidikan tinggi
(SMA/STM dan Akademik/ perguruan tinggi) berjumah 73 orang $(73 \%)$, dan diketahui sebanyak 67 orang $(67 \%)$ responden memiliki lingkar lengan atas (LILA) $23,5 \mathrm{~cm}$.

Menurut asumsi peneliti, terdapat Gambaran Pengetahuan Ibu hamil Tentang KEK (kekurangan energi kronis) disebabkan oleh factor pendidikan, dimana pendidikan sangat mempengaruhi penegtahuan yang diperoleh. Dari hasil penelitian didapatkan mayoritas pendidikan ibu hamil di Puskesmas Rejosari adalah SMA dengan jumlah 73 responden $(73 \%)$ maka terlihat jelas bahwa pendidikan sangat dipengaruhi pengetahuan. Faktor lain yang mempengaruhi yaitu umur ibu, dimana pada usia reproduksi 20-23 tahun seseorang mempunyai rasa ingin tahuyang sangat tinggi. Dari hasil penelitian didapatkan ibu > 20-23 tahun sebanyak 85 ibu hamil (85\%), dimana daya ingat dan rasa ingin tahu responden menurun.Karena penegtahuan ibu baik sehingga ibu tersebut bisa mengalami status gizi normal. Pengetahuan seseorang dapat berguna sebagai motivasi dalam bersikap dan bertindak sesuatu bagi orang tersebut.

\section{KESIMPULAN}

Berdasarkan dari hasil penelitian yang telah dilakukan di Puskesmas Rejosari 
Pekanbaru Tahun 2015, dapat ditarik kesimpulan sebagian besar ibu hamil di Puskesmas Rejosari berpengetahuan kurang (96\%) mengenai KEK (kekurangan energi kronis) pada kehamilan.

\section{SARAN}

1. Bagi Tempat Penelitian

Disarankan pada Puskesmas

Rejosarikhususnya tenaga kesehatan pelayanan KIA dan kader dapat memprioritaskan pemberian penyuluhan tentang KEK di Puskesmas maupun pada kegiatan Posyandu, melakukan pemeriksaan KEK pada saat hamil maupun sebelum hamil, dan memasang poster tentang KEK dan membagikan brosur tentang KEK (kekurangan energi kronis)dalam kehamilan pada ibu hamil.

2. Bagi Institusi Pendidikan

Disarankan pada STIKes Hang Tuah sebaiknya membantu memberikan penkes, atau bekerja sama dengan puskesmas untuk memberikan penyuluhan tentangKEK(kekurangan energi kronis), dan bagaimana tentang gizi pada saat kehamilan. sehingga pendidikan akan lebih meningkatkan pemberian materi tentang gizi ibu hamil kepada mahasiswa.
3. Bagi peneliti selanjutnya

Diharapkan kepada peneliti selanjutnya agar bisa membuat metode lain dan mengenai faktorfaktor lain yang berhubungan dengan kejadian KEK di Puskesmas Rejosari.

\section{DAFTAR PUSTAKA}

Aguswilopo, Siswanto. 2004. Strategi Meningkatkan Kualitas Pelayanan KB dalam Upaya Menurunkan Kematian Maternal. Jakarta : BKKBN

Mulyono Joyomartono. 2004. Pengantar Antropologi Kesehatan. Semarang: UNNES Press.

Amirudin. 2004. Gizi untuk kesehatan ibu dan anak. Yogyakarta : Graha Ilmu Arisman, 2004. Gizi untuk kesehatan ibu dan anak. Yogyakarta : Graha Ilmu Notoatmodjo, Soekidjo. Dr. 2003. Ilmu Kesehatan Masyarakat. Jakarta : Rineka Karya Cipta

Notoatmodjo, Soekidjo. Dr. 2010. Ilmu Kesehatan Masyarakat. Jakarta : Rineka Karya Cipta

Proverawati, A, dkk. 2009. Buku ajar gizi untuk kebidanan. Yogyakarta :

Nurhamedika

Retna Ningsih, R. AJ. 2010. Gizi untuk kesehatan ibu dan anak. Yogyakarta : Graha Ilmu 
Depkes RI. 2002. Upaya Kesehatan

Kerja Sektor Informal di Indonesia.

Jakarta: Depkes RI

Depkes RI. 2004. Upaya Kesehatan

Kerja Sektor Informal di Indonesia.

Jakarta: Depkes RI

Depkes RI. 2007. Upaya Kesehatan

Kerja Sektor Informal di Indonesia.

Jakarta: Depkes RI

Depkes RI. 2010. Upaya Kesehatan

Kerja Sektor Informal di Indonesia.

Jakarta: Depkes RI

Dinas Kesehatan Propinsi Pekanbaru.

2013. Profil Kesehatan riau tahun

2013. Pekanbaru: Dinkes

pekanbaru

Dinas Kesehatan Kota Padang. 2014.

Profil Kesehatan Kota Padang tahun

2014. Pekanbaru : Dinkes Kota

pekanbaru
Notoatmodjo, Soekidjo. Dr. 2003. Ilmu

Kesehatan Masyarakat. Jakarta :

Rineka Karya Cipta 2002.

Metodelogi Penelitian Kesehatan.

Jakarta: Rineka Karya Cipta

Mustika Hidayati. 2013. Kurang Energi

Kronis dan Anemia Ibu Hamil

Sebagai Faktor Resiko Kejadian

Berat Bayi Lahir Rendah Di Kota

Mataram

Desta, Y.2008. Faktor-faktor Yang

Berhubungan Dengan Resiko

Kurang Energi Kronis (KEK) Pada

Ibu Hamil di Wilayah Kerja

Puskesmas Batipuh II Kecamatan

Batipuh Selatan Kabupaten Tanah

Datar Tahun 2008. STIKes Mercu

bakti jaya Padang 
